\title{
Gambaran Penderita Tuberculosis Multi Drug Resisten(TB MDR) Di RSUD Dr. H. Abdul Moeloek Provinsi Lampung Januari-Desember 2015
}

\author{
Nadia Azzahro Rona Safitri ${ }^{1}$, Misbahul Huda ${ }^{2}$, Marhamah $^{2}$ \\ ${ }^{1}$ Program Studi D III Analis Kesehatan Politeknik Kesehatan Tanjungkarang \\ ${ }^{2}$ Jurusan Analis Kesehatan Politeknik Kesehatan Tanjungkarang
}

\begin{abstract}
Abstrak
Tuberculosis Multi Drug Resisten (TB MDR) adalah keadaan dimana kuman Mycobacterium tuberculosis sudah tidak dapat lagi dibunuh dengan salah satu atau lebih Obat Anti Tuberculosis (OAT). TB MDR terjadi bila penderita putus berobat sebelum masa pengobatan selesai atau penderita sering putus-putus minum obat selama menjalani pengobatan TB. Menurut WHO, Indonesia berada diperingkat 8 dari 27 negara dengan beban TB MDR terbanyak di dunia. Menurut hasil Pusat Data dan Informasi Kementerian Kesehatan RI tahun 2014 TB MDR di Indonesia terus mengalami peningkatan. Tujuan dari penelitian ini adalah untuk mengetahui gambaran penderita Tuberculosis Multi Drug Resisten (TB MDR) di RSUD dr. H. Abdul Moeloek Provinsi Lampung periode Januari-Desember 2015. Penelitian ini bersifat deskriptif. Populasi pada penelitian ini adalah seluruh penderita TB yang melakukan pemeriksaan resisten Obat Anti Tuberculosis (OAT) di RSUD Dr. H. Abdul Moeloek Provinsi Lampung pada tahun 2015 sebanyak 246 penderita. Sampel dalam penelitian ini adalah seluruh populasi. Hasil penelitian diperoleh data sebanyak 29 penderita yang mengalami resistensi rifampicin. Berdasarkan umur penderita TB MDR terbanyak kelompok 26-45 tahun sebanyak 15 penderita $(51,72 \%)$, kelompok 12-25 tahun sebanyak 9 penderita (31,03\%), kelompok 46-65 tahun sebanyak 5 penderita $(17,24 \%)$, dan terendah $>66$ tahun 0 penderita $(0 \%)$. Berdasarkan jenis kelamin penderita TB MDR terbanyak adalah perempuan sebanyak 15 penderita $(51,72 \%)$ dan laki-laki sebanyak 14 penderita $(48,27 \%)$.
\end{abstract}

Kata kunci : Tuberculosis, Tuberculosis Multi Drug Resisten (TB MDR)

\section{Description Of Tuberculosis Multi Drug Resisten (MDR TB) Patients In RSUD Dr. H. Abdul Moeloek Province Lampung Januari-December 2015}

\begin{abstract}
Tuberculosis Multi Drug Resistant (MDR TB) is a condition where Mycobacterium tuberculosis germs can no longer be killed with one or more Anti Tuberculosis Drugs (OAT). MDR TB occurs when the patient has dropped out of treatment before the treatment is over or the patient is often dotted to take medication during TB treatment. According to WHO, Indonesia is ranked 8th out of 27 countries with the highest burden of MDR TB in the world. According to the Ministry of Health of Indonesia data and information Center 2014 MDR TB in Indonesia continues to increase. The purpose of this study was to know the description of patients with Multi Drug Resistant Tuberculosis (MDR TB) in dr. H. Abdul Moeloek Lampung Province period January-December 2015. This research is descriptive. The population in this study were all TB patients who did anti-tuberculosis drug resistance test (OAT) at RSUD Dr. H. Abdul Moeloek Lampung Province in 2015 as many as 246 patients. The sample in this study is the entire population. The results obtained data as many as 29 patients who experience rifampicin resistance. Based on the age of patients with MDR TB, most of the 26-45 year group were 15 patients $(51.72 \%), 12-25$ years old group of 9 patients $(31.03 \%), 46-65$ years group, 5 patients $(17.24 \%$, and lowest> 66 years 0 patients $(0 \%)$. Based on sex of MDR tuberculosis most of the women are 15 patients $(51,72 \%)$ and male counted 14 patient $(48,27 \%)$.
\end{abstract}

Keywords: Tuberculosis, Tuberculosis Multi Drug Resistant (MDR TB)

Korespondensi : Misbahul Huda, Jurusan Analis Kesehatan Politeknik Kesehatan Tanjungkarang, Jl. SoekarnoHatta No. 1 Bandar Lampung, mobile: 081383294939,e-mail: misbahulhuda48@ymail.com 


\section{Pendahuluan}

Tuberculosis (TB) adalah suatu penyakit infeksi menular yang disebabkan bakteri Mycobacterium tuberculosis, yang dapat menyerang berbagai organ, terutama paru-paru. Penyakit ini bila tidak diobati atau pengobatannya tidak tuntas dapat mengakibatkan komplikasi berbahaya hingga kematian. Tuberculosis resisten obat (tuberculosis multi drug resisten/TB MDR) adalah keadaan dimana kuman Mycobacterium tuberculosis sudah tidak dapat lagi dibunuh dengan salah satu atau lebih Obat Anti Tuberculosis (OAT) (Kemenkes RI, 2015).

Prevalensi TB MDR di dunia diperkirakan 2-3 kali lipat lebih tinggi dari insidens. Global TB report dari WHO tahun 2011 mengenai hasil surveilans resistansi OAT di beberapa negara menunjukkan terdapatnya negara atau wilayah yang memiliki angka resistansi terhadap OAT yang sangat tinggi dan telah menghadapi ancaman endemi dan epidemi TB MDR (Kemenkes RI, 2013). Peningkatan jumlah kasus terdapat di beberapa negara antara tahun 2013-2014 adalah India, China, Federasi Rusia, dan Myanmar. Menurut WHO, diperkirakan kasus TB MDR sebesar 3,3\% dari kasus baru dan 20\% dari kasus yang sebelumnya secara global, dan diperkirakan 190.000 orang meninggal karena kasus TB MDR (WHO, 2015).

Indonesia berada diperingkat 8 dari 27 negara dengan beban TB MDR terbanyak di dunia dengan perkiraan pasien TB MDR di Indonesia terdapat 6.800 kasus baru TB dengan Tuberculosis Multi Drug Resisten (TB MDR) setiap tahun (WHO, 2015). Angka TB MDR diperkirakan sebesar $2 \%$ dari kasus TB baru dan 12\% dari kasus TB pengobatan ulang. Pasien Tuberculosis Multi Drug Resisten (TB MDR) sebanyak 55\% belum terdiagnosis atau mendapat pengobatan dengan baik dan benar (Kemenkes RI, 2015).

Pusat Data dan Informasi Kementerian Kesehattan RI (2014) mendata pada tahun 2009 terdata penderita TB MDR di Indonesia sebanyak 66 penderita, tahun 2010 sebanyak 216 penderita, tahun 2011 sebanyak 460 penderita, tahun 2012 sebanyak 696 penderita, tahun 2013 sebanyak 1.094 penderita, tahun 2014 sebanyak 1.752 penderita, tahun 2015 sebanyak 1.860 penderita. Data tersebut menunjukkan peningkatan jumlah penderita TB
MDR setiap tahun di Indonesia (Kemenkes RI, 2016).

Hasil penelitian Munir (2010) di RSU Persahabatan persentase penderita TB MDR menurut jenis kelamin periode 1 Januari 200531 Desember 2007 tercatat laki-laki 53 penderita $(52,5 \%)$ dan perempuan 48 penderita (47,5\%). Hasil penelitian Reviono (2014) di RSUD Dr. Moewardi Sukarta periode Januari 2011-Juni 2013 bahwa jumlah penderita TB MDR adalah 114 orang, 56 laki-laki dan 58 perempuan. Secara epidemiologi dibuktikan terdapat perbedaan antar laki-laki dan perempuan dalam hal penyakit infeksi, progresivitas penyakit, insidens dan kematian akibat TB. Jumlah penderita TB yang meningkat juga dapat menyebabkan peingkatan jumlah penderita TB MDR. Perbedaan antara laki-laki dan perempuan juga mempengaruhi perkembangan penyakit dimana perempuan mempunyai penyakit lebih berat pada saat datang ke rumah sakit. Perempuan lebih sering terlambat datang ke pelayanan kesehatan dibandingkan dengan laki-laki. Hal ini mengkin berhubungan dengan aib dan rasa malu lebih dirasakan pada perempuan dibandigkan lakilaki. Perempuan juga lebih sering mengalami kekhawatiran akan dikucilkan dari keluarga dan lingkungan akibat penyakitnya.

Hasil penelitian Munir (2010) di RSU Persahabatan persentase penderita TB MDR menurut usia periode 1 Januari 2005-31 Desember 2007 usia 15-24 tahun terdata 12 penderita $(11,7 \%)$, usia $25-34$ tahun terdata 36 penderita $(35,6 \%)$, usia $35-44$ tahun terdata 19 penderita $(18,8 \%)$, usia $45-55$ tahun terdata 27 pendereita $(26,7 \%)$, dan usia $>55$ tahun terdata 7 penderita (6,9\%). Data diatas jumlah penderita TB MDR terbanyak merupakan usia produktif berkisar 25-34 tahun. Umur produktif sangat berbahaya terhadap tingkat penularan karena pasien mudah berinteraksi dengan orang lain, mobilitas yang tinggi dan memungkinkan untuk menular ke orang lain serta lingkungan sekitar tempat tinggal.

Tuberculosis Multi Drug Resisten (TB MDR) merupakan hambatan dan menjadi masalah yang paling besar terhadap program pencegahan dan pemberantasan TB dunia. Hal ini disebabkan karena angka kesembuhan pada pengobatan TB MDR relatif lebih rendah, disamping itu lebih sulit, mahal, dan lebih banyak efek samping yang akan ditimbulkannya. Masalah lain, penyebaran resisten obat di berbagai negara sering tidak diketahui serta penatalaksanaan penderita TB MDR tidak adekuat. Kinerja program 
penanggulangan TB paru di Kabupaten setempat/kota setempat terutama ketepatan diagnosis mikroskopik untuk menetapkan kasus dengan BTA (+), dan penanganan kasus termasuk peran Pengawas Menelan Obat (PMO) yang dapat berpengaruh pada tingkat kepatuhan penderita untuk minum obat ketersediaan Obat Anti Tuberculosis (OAT) yang cukup dan berkualitas sangat mempengaruhi angka TB MDR (Sinaga, 2013).

Tuberculosis Multi Drug Resisten (TB MDR) terjadi bila penderita putus berobat sebelum masa pengobatan selesai atau penderita sering putus-putus minum obat selama menjalani pengobatan TB. Pengobatan TB membutuhkan waktu panjang (sampai 6-8 bulan) untuk mencapai penyembuhan dan dengan panduan (kombinasi) beberapa macam obat, sehingga tidak jarang pasien berhenti minum obat sebelum masa pengobatan selesai yang berakibat pada kegagalan dalam pengobatan TB (Bagianda, 2010).

World Health Organization (2011) memperkenalkan manajemen terpadu untuk penanganan pasien TB Resistan obat yang disebut sebagai Programmatic Management of Drug Resistant TB (PMDT). Rencana Global Pengendalian TB (The Global Plan to Stop TB) 2006-2015 yang telah direvisi, secara global direncanakan untuk mengobati sekitar 1,6 juta pasien TB MDR di dunia pada tahun 2006 sampai 2015 dimana $60 \%$ dari jumlah pasien tersebut berada di negara-negara dengan beban TB MDR tinggi (MDR TB high burden countries) (Kemenkes RI, 2013).

Indonesia mendapat persetujuan dari Green Light Comiittee untuk melakukan pengobatan pada 100 pasien TB MDR pada tahun 2007. Indonesia memulai pengobatan pasien TB MDR di 2 lokasi yaitu di RS. Persahabatan Jakarta dan di RS. dr. Soetomo Surabaya sejak Agustus 2009. Pengembangan pelayanan pasien TB MDR akan dilakukan secara bertahap ke seluruh wilayah di Indonesia, agar seluruh pasien TB MDR mendapatkan akses pengobatan yang terstandar (Kemenkes RI, 2011)

Pengobatan TB resistan obat ditetapkan menjadi bagian dari Program Pengendalian TB Nasional dengan terbitnya Peraturan Menteri Kesehatan Republik Indonesia nomor 565/MENKES/PER/III/2011 perihal Strategi Nasional Pengendalian TB tahun 2011-2014. Kegiatan ini pada awalnya dikenal sebagai Programmatic Management of Drug Resistant TB (PMDT), untuk selanjutnya kegiatan ini disebut sebagai Manajemen Terpadu
Pengendalian TB Resistan Obat (MTPTRO) (Kemenkes RI, 2013).

RSUD dr. H. Abdul Moeloek merupakan rumah sakit umum daerah tipe B yang menjadi rumah sakit rujukan rumah sakit di Kabupaten dan puskesmas. Rumah sakit ini merupakan salah satu rumah sakit yang memiliki fasilitas pelayanan TB MDR di Provinsi Lampung, sedangkan untuk rumah sakit rujukan nasional untuk kasus TB MDR adalah RSU Persahabatan Jakarta. Hasil survey yang dilakukan di RSUD Dr. H. Abdul Moeloek untuk pemeriksaan resisten obat anti tuberculosis, setiap bulan sekitar 60 orang, dimana sekitar 10 orang yang terdiagnosa positif resisten obat anti tuberculosis

Tuberculosis (TB) adalah penyakit infeksi menular yang disebabkan oleh Mycobacterium tuberculosis. Kuman batang aerobik dan tahan asam ini, dapat merupakan organisme patogen maupun saprofit (Price, 2006). Bakteri Mycobacterium tuberculosis adalah bakteri berbentuk batang, ramping lurus berukuran sekitar $0,4 \times 3 \mu \mathrm{m}$. Bakteri ini memiliki sifat khusus yaitu sifat tahan terhadap asam. Pada pewarnaan Ziehl Neelsen bakteri Mycobacterium tuberculosis akan berwarna merah dengan latar belakang biru pucat (Brooks, 2008).
Ordo : Actinomycetales
Famliy : Mycobacteriaceae
Genus : Microbacterium
Spesies : Mycobacterium tuberculosis

(Sujudi, 1994)

TB MDR (Tuberculosis Multi Drug Resisten) adalah keadaan di mana kuman tersebut sudah tidak dapat lagi dibunuh dengan salah satu atau lebih Obat Anti Tuberculosis (OAT) (Kemenkes RI, 2015).

Tuberculosis resistensi OAT pada dasarnya adalah suatu fenomena buatan manusia, sebagai akibat dari pengobatan pasien TB yang tidak adekuat maupun penularan dari pasien TB resistan OAT (Kemenkes RI, 2013). Secara umum resistensi terhadap obat anti tuberculosis (OAT) dibagi menjadi:

a. Resistensi primer adalah apabila pasien sebelumnya tidak pernah mendapat pengobatan OAT.

b. Resistensi sekunder adalah apabila pasien telah mempunyai riwayat pengobatan OAT minimal 1 bulan (Soepandi, 2010)

$$
\text { Laporan WHO (2015) terjadi }
$$
peningkatan jumlah kasus TB MDR yang terdeteksi antara 2013 dan 2014 di India (23.162-25.748), China (4.183-5.807), Federasi 
Rusia (13.521-15.585), dan Myanmar (1.9843.495), dan terjadi pengurangan di Filipina, Afrika Selatan, Ukraina, Uzbekistan dan beberapa negara lain (WHO, 2015)

Indonesia telah melakukan beberapa survei resistansi OAT untuk mendapatkan data resistansi OAT. Survei tersebut diantaranya dilakukan di Kabupaten Timika Papua pada tahun 2004, menunjukkan data kasus TB MDR diantara kasus baru TB adalah sebesar 2\%, di Provinsi Jawa Tengah pada tahun 2006, data kasus TB MDR di antara kasus baru TB adalah 1,9\% dan kasus TB MDR pada TB yang pernah diobati sebelumnya adalah $17,1 \%$; di Kota Makasar pada tahun 2007, data kasus TB MDR diantara kasus baru TB adalah sebesar 4,1\% dan pada TB yang pernah diobati sebelumnya adalah 19,2\%. Hasil Survei terbaru yang dilakukan di Provinsi Jawa Timur pada tahun 2010 menunjukkan angka $2 \%$ untuk kasus baru dan $9,7 \%$ untuk kasus pengobatan ulang (Kemenkes RI, 2013)

Kegagalan pada pengobatan TB MDR akan menyebabkan lebih banyak OAT yang resisten kuman Mycobacterium tuberculosis. Faktor utama penyebab terjadinya resistansi kuman terhadap OAT adalah ulah manusia sebagai akibat tatalaksana pengobatan pasien TB yang tidak dilaksanakan dengan baik.

Terdapat 5 kategori resistansi terhadap Obat Anti Tuberculosis, yaitu:

a. Monoresistance: resistan terhadap salah satu Obat Anti Tuberculosis, misalnya resistan isoniazid $(\mathrm{H})$

b. Polyresistance: resistan terhadap lebih dari satu Obat Anti Tuberculosis, selain kombinasi isoniazid $(\mathrm{H})$ dan rifampisin (R), misalnya resistan isoniazid dan etambutol, rifampisin etambutol, isoniazid etambutol dan streptomisin, rifampisin etambutol dan streptomisin

c. Multi Drug Resistance (MDR): resistan terhadap isoniazid dan rifampisin, dengan atau tanpa Obat Anti Tuberculosis (OAT) lini pertama yang lain, misalnya resistan isoniazid $(\mathrm{H})$ dan rifampisin $(\mathrm{R})$

d. Extensively Drug Resistance (XDR): TB MDR disertai resistansi terhadap salah salah satu obat golongan fluorokuinolon dan salah satu dari Obat Anti Tuberculosis (OAT) injeksi lini kedua (kapreomisin, kanamisin dan amikasin).

e. TB Resistan Rifampisin (TB RR): resistan terhadap rifampisin (monoresistan, poliresistan, TB MDR, TB XDR) yang terdeteksi menggunakan metode fenotip atau genotip dengan atau tanpa resistan OAT lainnya (Kemenkes RI,2013).

Suspek TB resistan obat adalah semua orang yang mempunyai gejala $\mathrm{TB}$ yang memenuhi satu atau lebih kriteria suspek dibawah ini:

a. Pasien TB pengobatan kategori 2 yang gagal.

b. Pasien TB pengobatan kategori 2 yang tidak konversi setelah 3 bulan pengobatan

c. Pasien TB yang mempunyai riwayat pengobatan TB yang tidak standar serta menggunakan kuinolon dan obat injeksi lini kedua minimal selama 1 bulan

d. Pasien TB pengobatan kategori 1 yang gagal

e. Pasien TB pengobatan kategori 1 yang tetap positif setelah 3 bulan pengobatan.

f. Pasien TB kasus kambuh (relaps), kategori 1 dan kategori 2

g. Pasien TB yang kembali setelah loss to follow-up (lalai berobat/default)

h. Suspek TB yang mempunyai riwayat kontak erat dengan pasien TB MDR

i. Pasien ko-infeksi TB-HIV yang tidak respons terhadap pemberian OAT

Pasien yang memenuhi salah satu kriteria suspek TB resistan obat harus dirujuk secara sistematik ke RS Rujukan TB MDR untuk kemudian dikirim ke laboratorium rujukan TB MDR dan dilakukan pemeriksaan apusan BTA mikroskopis, biakan dan uji kepekaan Mycobacterium tuberculosis dengan metode konvensional maupun metode cepat (rapid test) (Kemenkes, 2013).

Pemeriksaan Laboratorium

a. Pemeriksaan mikroskopis

Pemeriksaan mikroskopis BTA dengan pewarnaan Ziehl Neelsen yang dilaksanakan untuk:

1) Pemeriksaan pendahuluan pada suspek $T B$ MDR yang dilanjutkan dengan biakan dan uji kepekaan Mycobacterium tuberculosis.

2) Pemeriksaan dahak lanjutan (follow-up) dalam waktu-waktu tertentu selama masa pengobatan diikuti dengan pemeriksaan biakan untuk memastikan bahwa Mycobacterium tuberculosis sudah tidak ada lagi

b. Uji kepekaan Mycobacterium tuberculosis terhadap Obat Anti Tuberculosis (OAT)

Ketepatan uji kepekaan Mycobacterium tuberculosis yang dilakukan dalam kondisi optimum bergantung kepada jenis obat yang diuji. Untuk lini pertama, ketepatan tertinggi adalah rifampisin $(\mathrm{R})$ dan isoniazid $(\mathrm{H})$ disusul streptomisin (S) dan etambutol (E). Sementara 
itu uji kepekaan Mycobacterium tuberculosis untuk pirazinamid $(Z)$ tidak dianjurkan karena tingkat kepercayaan dan keterulangannya belum terjamin.

$\begin{array}{cccc}\text { Uji } & \text { kepekaan } & \text { Mycobacterium } \\ \text { tuberculosis } & \text { terhadap } & \text { OAT lini }\end{array}$ kedua,aminoglikosida dan fluorokuinolon mempunyai tingkat kepercayaan dan keterulangan baik. Data tentang tingkat kepercayaan dan keterulangan untuk OAT lini kedua yang lain masih sangat terbatas bahkan ada yang belum dapat dilakukan.

Saat ini pemeriksaan uji kepekaan Mycobacterium tuberculosis secara cepat (rapid test) sudah direkomendasikan oleh WHO untuk digunakan sebagai penapisan (Kemenkes RI, 2013).

GeneXpert MTB/RIF alah suatu alat uji yang menggunakan catridge berdasarkan Nucleic Acid Amplification Test (NAAT) secara automatis untuk mendeteksi kasus TB dan resisten rifampisin dan memberikan hasil dalam waktu kurang lebih 2 jam (WHO, 2013).

Sistem GeneXpert diluncurkan pada tahun 2004, dan menyederhanakan pengujian molekuler dengan sepenuhnya mengintegrasikan dan mengotomatisasi tiga proses yang diperlukan untuk pengujian molekuler berbasis PCR real-time (yaitu, spesimen persiapan, amplifikasi dan deteksi). Sistem ini terdiri dari instrumen, komputer pribadi, scanner barcode dan software preloaded; cartridge sekali pakai sekali pakai mengandung reagen liofilisasi, buffer dan pencuci. Deteksi target dan karakterisasi dilakukan secara real time dengan menggunakan perangkat laser yang mendeteksi enam warna (WHO, 2014)

Penelitian yang dilakukan Boehme dalam Susanty (2015) menunjukkan bahwa pemeriksaan dengan GeneXpert MTB/RIF untuk mendiagnosa TB MDR mendapatkan sensitivitas yang tinggi $96,5 \%$ dan sensitivitas dalam mendeteksi resistensi rifampisin $96,1 \%$.

$$
\text { Langkah-langkah yang harus }
$$

dilaksanakan apabila terjadi perbedaan

hasil antara pemeriksaan rapid/tes cepat dibandingkan dengan hasil pemeriksaan biakan dan DST konvensional:

a) Dilakukan pemeriksaan ulang geneXpert jika hasil pemeriksaan geneXpert menunjukkan hasil rifampisin resistan tetapi hasil pemeriksaan biakan dan DST konvensional menunjukkan hasil rifampisin sensitif. Pemeriksaan ulang geneXpert ini untuk menyingkirkan terdapatnya resistansi terhadap rifampisin. b) Jika pemeriksaanulang geneXpert menunjukkan hasil rifampisin resistan maka pengobatan standar TB MDR diteruskan sampai selesai.

c) Jika pemeriksaan ulang geneXpert menunjukkan hasil sensitif rifampisin maka:

d) Pasien dengan hasil uji kepekaan konvensional hasilnya pan sensitif: sebaiknya tidak otomatis dilakukan perubahan tatalaksana pasien TB yang sebelumnya telah diberikan pengobatan TB MDR kemudian diganti menjadi pengobatan TB dengan OAT lini pertama. Sebaiknya kasus tersebut direview oleh Tim Ahli Klinis (TAK) dengan mempertimbangkan riwayat pengobatan TB sebelumnya dan kemungkinan risiko terjadinya TB MDR pada pasien tersebut.

e) Pasien dengan hasil uji kepekaan konvensional hasilnya mono resistan/ poli resistan selain rifampisin: dilakukan perubahan pengobatan menggunakan paduan OAT standar untuk pasien mono dan poli resistan. Sebelum memutuskan untuk mengganti paduan tersebut harus dipastikan bahwa Tim Ahli Klinis (TAK) telah mereview semua kemungkinan yang ada. (Kemenkes RI, 2013)

\section{Metode}

Jenis penelitian ini merupakan penelitian deskriptif, yaitu memberikan gambaran penderita TB MDR berdasarkan jenis kelamin dan usia yang tercatat di rekam medik RSUD Dr. H. Abdul Moeloek Provinsi Lampung periode Januari-Desember 2015.

Lokasi penelitian dilakukan di Laboratorium Patologi Klinik RSUD Dr. H. Abdul Moeloek Provinsi Lampung. Penelitian dilakukan pada bulan Januari-Mei 2017.

Populasi dalam penelitian ini adalah seluruh penderita TB yang melakukan pemeriksaan resisten Obat Anti Tuberculosis (OAT) di RSUD Dr. H. Abdul Moeloek Provinsi Lampung periode Januari-Desember 2015.

Sampel dalam penelitian ini adalah seluruh populasi yaitu seluruh penderita TB yang melakukan pemeriksaan resisten Obat Anti Tuberculosis (OAT) di RSUD Dr. H. Abdul Moeloek Provinsi Lampung periode Januari-Desember 2015.

Data yang dikumpulkan adalah data yang di peroleh dari rekam medik pemeriksaan TB 
yang positif terhadap resisten Obat Anti Tuberculosis (OAT) di RSUD Dr. H. Abdul Moeloek Provinsi Lampung periode bulan Januari-Desember 2015 kemudian dikelompokan berdasarkan jenis kelamin, dan usia.

Pengumpulan data dalam penelitian ini dilakukan dengan mencatat data dari rekam medik untuk menelusuri data berupa diagnosis dokter, nama, nomor rekam medik, usia dan jenis kelamin penderita TB MDR pada bulan Januari-Desember 2015. Serta data hasil pemeriksaan laboratorium pasien

Data diolah dan disajikan dalam bentuk tabel dan grafik, dimana penderita TB MDR dikelompokkan berdasarkan jenis kelamin dan usia, dan untuk mengetahui fluktuasi jumlah penderita TB MDR setiap bulannya selama Januari-Desember 2015 di RSUD Dr. H. Abdul Moeloek Provinsi Lampung.

\section{Hasil dan Pembahasan}

Jumlah penderita Tuberculosis Multi Drug Resisten (TB MDR) yang diperiksa di RSUD Dr. H. Abdul Moeloek Provinsi Lampung Januari-Desember 2015, dapat dilihat pada tabel dibawah ini:

Tabel 1. Persentase penderita Tuberculosis Multi Drug Resisten (TB MDR) di RSUD

Dr. H. Abdul Moeloek Provinsi Lampung Januari-Desember 2015

\begin{tabular}{cccccc}
\hline \multirow{2}{*}{ Bulan } & \multirow{2}{*}{ Suspek TB MDR } & \multicolumn{2}{c}{ Resisten Obat } & \multicolumn{2}{c}{ Persentase (\%) } \\
\cline { 3 - 5 } & & MDR & Non MDR & MDR & Non MDR \\
\hline Januari & 14 & 2 & 12 & 14,29 & 85,71 \\
Februari & 20 & 2 & 18 & 10,00 & 90,00 \\
Maret & 23 & 4 & 19 & 17,39 & 82,61 \\
April & 16 & 3 & 13 & 18,75 & 81,25 \\
Mei & 16 & 2 & 14 & 12,50 & 87,50 \\
Juni & 21 & 3 & 18 & 15,00 & 85,71 \\
Juli & 20 & 3 & 17 & 0,00 & 85,00 \\
Agustus & 26 & 0 & 26 & 00,00 & 00,00 \\
September & 0 & 0 & 0 & 10,34 & 89,00 \\
Oktober & 29 & 3 & 26 & 6,67 & 93,33 \\
November & 30 & 2 & 28 & 16,13 & 83,87 \\
Desember & 31 & 5 & 26 & 11,79 & 88,21 \\
\hline Total & 246 & 29 & 217 & & \\
\hline
\end{tabular}

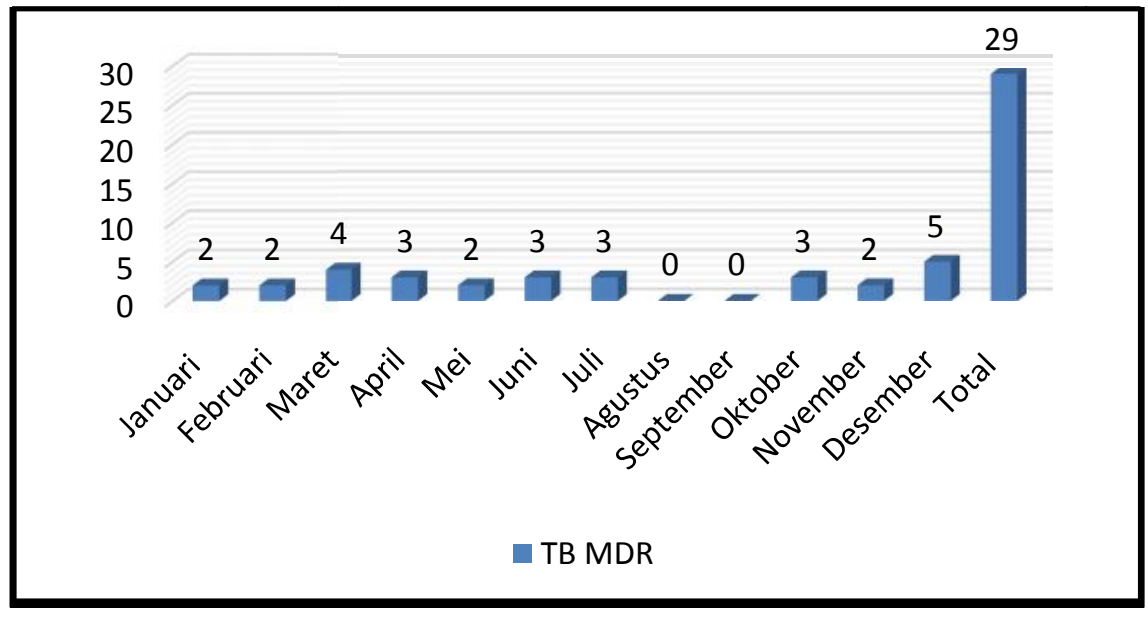

Grafik 1 Fluktuasi TB MDR di RSUD Dr. H. Abdul Moeloek Januari-Desember 2015 
Tabel 2. Persentase penderita Tuberculosis Multi Drug Resisten (TB MDR) berdasarkan jenis kelamin di RSUD Dr. H. Abdul Moeloek Provinsi Lampung Januari-Desember 2015

\begin{tabular}{ccc}
\hline \multirow{2}{*}{$\begin{array}{c}\text { Bulan } \\
\text { Januari-Desember 2015 }\end{array}$} & Persentase & Januari-Desember 2015 \\
\cline { 2 - 3 } & $\mathrm{N}$ & \\
\hline Laki-laki & 14 & Laki-laki \\
\hline Perempuan & 15 & Perempuan \\
\hline Total & 29 & 100,00 \\
\hline
\end{tabular}

Tabel 3. Persentase penderita Tuberculosis Multi Drug Resisten (TB MDR) berdasarkan usia di RSUD Dr. H. Abdul Moeloek Provinsi Lampung Januari-Desember 2015

\begin{tabular}{|c|c|c|c|c|c|c|c|c|c|}
\hline \multirow{3}{*}{ Bulan } & \multirow{3}{*}{$\begin{array}{l}\text { Penderita } \\
\text { TB MDR }\end{array}$} & \multicolumn{8}{|c|}{ Usia } \\
\hline & & \multicolumn{2}{|c|}{$\begin{array}{l}\text { (12-25 } \\
\text { tahun) }\end{array}$} & \multicolumn{2}{|c|}{$\begin{array}{l}\text { (26-45 } \\
\text { tahun) }\end{array}$} & \multicolumn{2}{|c|}{$\begin{array}{l}\text { (46-65 } \\
\text { tahun) }\end{array}$} & \multicolumn{2}{|c|}{ ( $>66$ tahun) } \\
\hline & & $\mathrm{n}$ & $\%$ & $\mathrm{n}$ & $\%$ & $\mathrm{n}$ & $\%$ & $\mathrm{~N}$ & $\%$ \\
\hline $\begin{array}{c}\text { Januari- } \\
\text { Desember } \\
2015\end{array}$ & 29 & 9 & 31,03 & 15 & 51,72 & 5 & 17,24 & 0 & 00,00 \\
\hline Total & 29 & 100 & & & & & & & \\
\hline
\end{tabular}

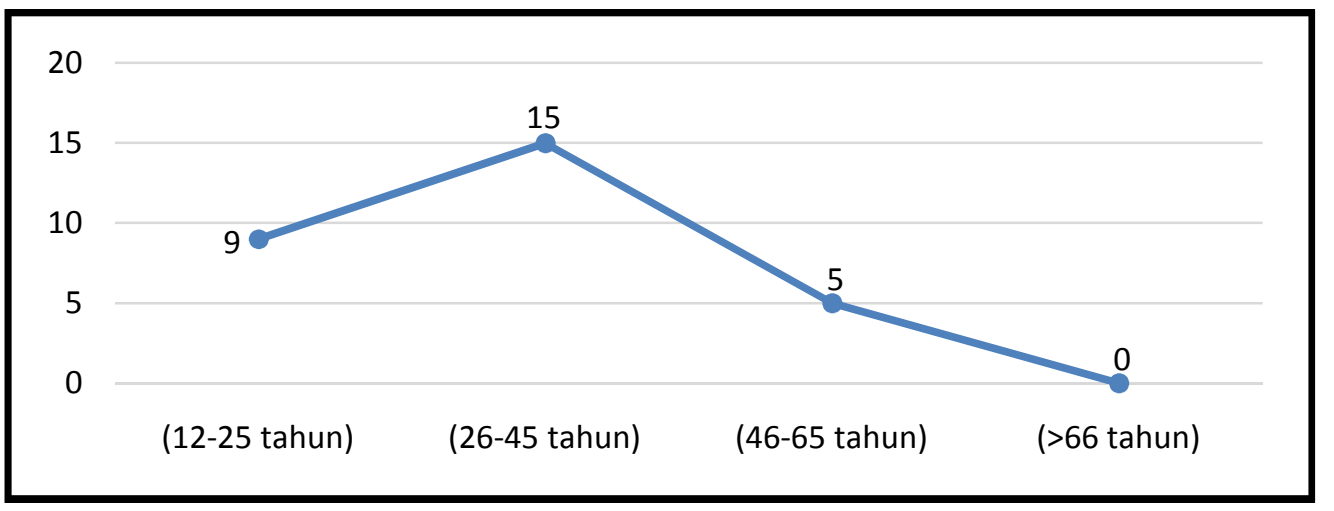

Grafik 2 Fluktuasi TB MDR berdasarkan usia di RSUD Dr. H. Abdul Moeloek Januari-Desember 2015

Berdasarkan data hasil rekam medik pemeriksaan TB MDR di RSUD Dr. H. Abdul Moeloek Provinsi Lampung Januari-Desember 2015 yang tercantum pada tabel 1 dapat diketahui sampel dahak suspek penderita TB MDR setiap bulannya. Hasil pemeriksaan TB MDR adalah 29 penderita dari 246 penderita yang melalukan pemeriksaan TB MDR. TB MDR adalah keadaan dimana kuman Mycobacterium tuberculosis sudah tidak dapat lagi diobati dengan salah satu atau lebih Obat Anti Tuberculosis (OAT) (Kemenkes RI, 2015).

Pemeriksaan TB MDR pada tahun 2015 mengalami peningkatan yang cenderung stabil, peningkatan penderita TB MDR terjadi pada bulan Januari ke bulan Maret yaitu 2 penderita menjadi 4 penderita dan menurun pada bulan
April dan Mei, yaitu 3 penderita menjadi 2 penderita. Peningkatan kembali terjadi pada bulan Juni dan Juli yaitu 3 penderita kemudian menurun pada bulan Agustus yaitu 0 penderita. Peningkatan terjadi pada bulan Oktober yaitu 3 penderita, kemudian menurun pada bulan November yaitu 2 penderita, dan meningkat pada bulan Desember yaitu 5 penderita, sedangkan pada bulan September tidak dilakukan pemeriksaan TB MDR yang disebabkan tidak tersedia cartridge. Cartridge adalah tempat reagen dan sampel untuk mendeteksi TB MDR pada alat Genexpert. Peningkatan jumlah TB MDR ini kemungkinan disebabkan ada beberapa faktor, antara lain tingkat kepatuhan penderita dalam minum obat yang rendah dikarenakan tidak nyaman 
terhadap efek samping obat dan terlalu lama masa pengobatan. Hasil penelitian ini sesuai dengan penelitian Fauziah (2013) bahwa pasien yang tidak patuh dalam pengobatan memiliki peluang 10,8 kali untuk mengalami TB MDR dibandingkan dengan penderita yang patuh terhadap pengobatan. Berdasarkan Kemenkes RI (2014) tentang pedoman nasional pengendalian Tuberculosis, tugas pokok pengawasan menelan obat (PMO) selama penderita menjalani pengobatan dari awal sampai akhir sebagai berikut : mengawasi penderita setiap kali menelan obat, mendorong penderita agar berobat teratur, mengingatkan penderita untuk periksa dahak ulang, dan memberikan penjelasan kepada penderita akibat menelan obat secara tidak teratur.

Tabel 2 menunjukkan penderita yang memiliki hasil pemeriksaan TB MDR di RSUD Dr. H. Abdul Moeloek Provinsi Lampung Januari-Desember 2015 berdasarkan jenis kelamin, didapatkan jumlah terbanyak adalah perempuan sebanyak 15 penderita $(51,72 \%)$ dan laki-laki sebanyak 14 penderita $(48,27 \%)$. Hasil ini relatif seimbang antara laki-laki dengan perempuan dengan hasil selisih yang tidak jauh berbeda. Hasil ini sesuai dengan penelitian Reviono (2014) bahwa penderita TB MDR lebih banyak terjadi pada perempuan yaitu lakilaki 56 penderita $(46,5 \%)$ dan perempuan 58 penderita $(50,9 \%)$. Hal ini kemungkinaan dikarenakan perempuan lebih sering terlambat ke pelayanan kesehatan dibandingkan dengan laki-laki, dan kemungkinan berhubungan dengan rasa malu sehingga sering mengalami kekhawatiran akan dikucilkan dari keluarga dan lingkungan akibat penyakitnya.

Tabel 3 menunjukkan penderita yang memiliki hasil pemeriksaan TB MDR di RSUD Dr. H. Abdul Moeloek Provinsi Lampung Januari-Desember 2015 berdasarkan usia, jumlah terbanyak kelompok 26-45 tahun sebanyak 15 penderita $(51,72 \%)$, kemudian kelompok 12-25 tahun sebanyak 9 penderita $(31,03 \%)$, diikuti kelompok 46-65 tahun sebanyak 5 penderita $(17,24 \%)$, dan terendah $>66$ tahun 0 penderita (0\%). Hal ini sesuai dengan hasil penelitian Sinaga (2013) bahwa penderita TB MDR terbanyak pada usia produktif. Pada penelitian yang di lakukan Susan dalam Fauziah (2013) menunjukkan bahwa pasien TB yang berusia muda secara signifikan lebih beresiko untuk menjadi TB MDR dikarenakan faktor-faktor berisiko seperti alkohol, dan infeksi HIV, sehingga hal tersebut dapat menjadi salah satu alasan kenapa usia muda lebih memiliki risiko yang lebih besar untuk menjadi TB MDR dibandingkan dengan yang lebih tua. Menurut Fauziah (2013) semakin tinggi tingkat konsumsi alkohol maka semakin berisiko untuk TB MDR dan mengkonsumsi alkohol memiliki peluang 1,5 kali untuk TB MDR dibandingkan dengan yang tidak mengkonsumsi alkohol. Penelitian yang dilakukan Masniari et al dalam Fauziah (2013) bahwa alkohol dapat menyebabkan gangguan sistem kekebalan tubuh sehingga terjadi reaktivasi infeksi TB laten. Faktor risiko TB MDR lainnya adalah infeksi HIV, pada penderita HIV terjadi kerusakan cellular imunity yang dapat menyebabkan infeksi opportunistik seperti TB. Infeksi opportunistik adalah infeksi yang terjadi apabila sistem kekebalan tubuh seseorang mengalami penurunan, sehingga berisiko tertularnya penyakit seperti TB.

Berdasarkan data rekam medik pemeriksan TB MDR di RSUD Dr. H. Abdul Moeloek Provinsi Lampung dapat disimpulkan bahwa:

1. Persentase penderita TB MDR di RSUD Dr. H. Abdul Moeloek Provinsi Lampung Januari-Desember 2015 adalah 29 penderita $(11,79 \%)$ dari 246 suspek penderita TB MDR

2. Persentase penderita TB MDR berdasarkan jenis kelamin di RSUD Dr. H. Abdul Moeloek Provinsi Lampung JanuariDesember 2015 menunjukkan kelompok jenis kelamin laki-laki yaitu 14 penderita $(48,27 \%)$ sedangkan perempuan yaitu 15 penderita $(51,72 \%)$.

3. Persentase penderita TB MDR berdasarkan kelompok usia di RSUD Dr. H. Abdul Moeloek Provinsi Lampung JanuariDesember 2015 menunjukkan kelompok remaja yaitu 9 penderita $(31,03 \%)$, kelompok dewasa yaitu 15 penderita $(51,72 \%)$, kelompok lansia yaitu 5 penderita $(17,24 \%)$, dan kelompok manula 0 penderita $(0 \%)$.

\section{Daftar Pustaka}

1. Bagianda IM, Primasari NLP 2010, Faktor-Faktor yang Mempengaruhi Tingkat Ketidakpatuhan Penderita Tuberkulosis dalam Berobat di Poliklinik DOTS RSUP Sanglah Denpasar. J Peny Dalam, 11(3), pp.158-163.

2. Brooks FG, Butel SJ, Morse AS 2008, Jawetz,Melnick, dan Adelberg: 
Mikrobiologi Kedokteran, Edisi 23, Jakarta: Buku Kedokteran EGC.

3. Fauziah LA 2013, Faktor-Faktor Yang Berpengaruh Terhadap Kejadian Tuberculosis Multidrug Resistent(TB MDR) di RSUP Persahabatan tahun 2013, Departemen Epidemiologi FKM UI

4. Kementerian Kesehatan RI 2011, Programmatic Management of Drug Resistance Tuberculosis Pengendalian Tuberculosis, Jakarta: Dit.Jen.PP dan PL.

5. Kementerian Kesehatan RI 2013, Petunjuk Teknis Manajemen Terpadu Pengendalian Tuberkulosis Resisten Obat, Jakarta: Dit.Jen.PP dan PL.

6. Kementerian Kesehatan RI 2014, Pedoman Pengendalian Tuberculosis, Jakarta: Dit.Jen.PP dan PL.

7. Kementerian Kesehatan RI 2015, Pedoman Pengendalian Tuberculosis, Jakarta: Dit.Jen.PP dan PL.

8. Kementerian Kesehatan RI 2016, Tuberculosis: Temukan Obati Sampai Sembuh, Jakarta: Pusadatin.

9. Munir SM; Nawas A; Soetoyo DK 2010, Pengamatan Pasein Tuberculosis Paru dengan Multidrug Resistant (TB MDR) di Poliklinik RSUP Persahabatan. J Respir Indo, 30(2), pp.92-104.

10. Price SA dan Wilson ML 2006, Patofisiologi Konsep Klinik Proses-Proses Penyakit, Edisi 6, Jakarta: Buku Kedokteran EGC.

11. Reviono; at all 2014, Multi Resistent Tuberculosis (MDR-TB): Tinjauan Epidemiologi dan Faktor Risiko Efek Samping Obat Anti Tuberculosis. MKB, 46(4),pp. 190-196.
12. Sinaga MYB 2013, Karakteristik Penderita Multi Drug Resisten Tuberculosis yang Mengikuti Programmatic Management of Drug Resisten Tuberculosis di Rumah Sakit Umum Pusat Haji Adam Malik Medan, J Respir Indo, 33(4),pp.221-229.

13. Sihombing H; dkk 2012, Pola Resistensi Primer pada Penderita TB Paru Kategori I di RSUD H. Adam Malik Medan, J Respir Indo, 32(3),pp.138-145.

14. Soepandi PZ 2010, Diagnosis dan Faktor yang Mempengaruhi Terjadinya TB MDR, Jurnal Tuberkulosis Indonesia, 7,pp.16-19.

15. Sujudi 1994, Mikrobilogi Kedokteran,Edisi Revisi, Jakarta: Binarupa Aksara

16. Susanty E; dkk 2015, Uji Diagnostik GeneXpert MTB/RIF di Rumah Sakit Umum Pusat Haji Adam Malik Medan, Jurnal Biosains, 1(2),pp.19-30.

17. World Health Organization 2015, Global Tuberculosis report 2015. Tersedia at: http://apps.who.int/iris/bitstream/10665/19 1102/1/9789241565059 eng.pdf [Diakses Januari 20, 2017]

18. World Health Organization 2014, Xpert MTB/RIF Implementation Manual: Techinal and Operational "how-to" Practical Consideration :dia at: http://apps.who.int/iris/bit $\quad 10665 / . . . /$ 9789241506700_eng.pdf 2s Januari $20,2017]$ 